\title{
Novel Acaricidal Drug Fluazuron Causes Immunotoxicity via Selective Depletion of Lymphocytes T CD8
}

\author{
Juliana Gonçalves Ribeiro, ${ }^{1,2}$ Anelise Santos Soares, ${ }^{2}$ \\ Pamella Eduardha Espindola Chaves, ${ }^{2}$ Jéssica Tamara Limberger, ${ }^{2}$ Emanoeli da Rosa, ${ }^{1,2}$ \\ Luísa Zuravski, ${ }^{2}$ Luís Flávio Souza de Oliveira, ${ }^{1,2}$ and Michel Mansur Machado $\mathbb{D}^{1,2}$ \\ ${ }^{1}$ Postgraduate Program in Pharmaceutical Sciences, Federal University of Pampa, BR 472, Km 585, Mailbox 118, \\ CEP: 97500-970, Uruguaiana, RS, Brazil \\ ${ }^{2}$ TOXCEL-Cellular Toxicology Research Group, Federal University of Pampa, BR 472, Km 585, Mailbox 118, \\ CEP: 97500-970, Uruguaiana, RS, Brazil
}

Correspondence should be addressed to Michel Mansur Machado; michelmachado@unipampa.edu.br

Received 29 January 2019; Accepted 22 April 2019; Published 7 May 2019

Academic Editor: Jairo Kennup Bastos

Copyright (C) 2019 Juliana Gonçalves Ribeiro et al. This is an open access article distributed under the Creative Commons Attribution License, which permits unrestricted use, distribution, and reproduction in any medium, provided the original work is properly cited.

\begin{abstract}
Fluazuron is one of the newest veterinary antitick medicines. Belonging to the benzoylphenylureas group, its mechanism of action acts by the interference of the formation of the chitin of the tick, which is responsible for the hardening of its exoskeletons. In addition to taking care of the health of the animal so that it receives the medication in the doses and the correct form, it is important to analyze the safety of the operator. Reduced resistance to infectious disease was a well-documented consequence of primary and acquired immunodeficiencies, but a novel finding following xenobiotic exposure. The awareness of the consequences of altered immune function is the most likely outcome of inadvertent exposure. The human health implications of studies in which chemical exposure reduced resistance to infection drove an early focus on immunosuppression within the toxicology community. The main objective is to perform the evaluation by computational platforms and in cell culture, searching for data that can serve as a foundation for a better understanding of the toxic effects involved with the accidental contamination of Fluazuron and, thus, to assist the medical community and users to understand the risks inherent in its use. As far as we can determine in the literature, our work has unmistakably demonstrated that the Fluazuron can cause genotoxicity by probable chromatin rearrangement and immunodepleting by specific reduction of the CD8 T lymphocyte subpopulation, mediated by the decrease in gamma interferon production. Although the use of Fluazuron is a necessity for tick control and for cattle management, we must bear in mind that the imminent risks to its application exist. Careless use can damage the immune system which in turn carries a gigantic hazard by opening a door to diseases and pathogens and leaving us defenseless.
\end{abstract}

\section{Introduction}

In recent years there have been several changes in beef cattle, with modern production applications, which allowed the sector to increase volume and productivity [1]. Due to the increase in animal production, there was a multiplication of the cases of parasitism, developing a wide range of parasitic species, one among them being the tick Rhipicephalus (Boophilus) microplus [2].

One of the main control methods for the tick is the use of acaricides, the main ones being applied under immersion, spray, pour-on, and injectable formulations and the latter two being classified as systemic action [3].

In the market there are several active principles and formulations. Fluazuron (N-[[4-chloro-3-[3-chloro-5-(trifluoromethyl)pyridin-2-yl] oxyphenyl]carbamoyl]-2,6-difluorobenzamide) (Figure 1) is one of the newest veterinary antitick medicines, which has the "pour-on" formula in which it means to apply the drug along the animal's back [4]. Belonging to the benzoylphenylureas group, its mechanism of action acts by the interference of the formation of the chitin of the tick, which is responsible for the hardening 


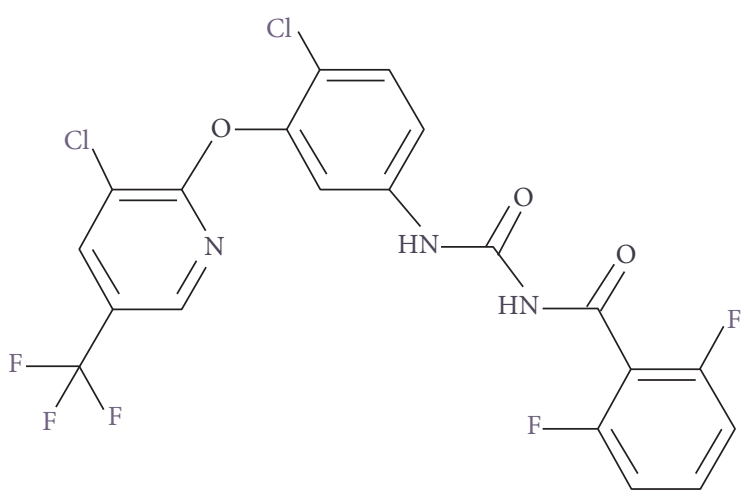

FIGURE 1: Fluazuron chemical structure [9].

of its exoskeletons [5]. After administration of Fluazuron, absorption occurs slowly, and elimination can be observed for 3-4 weeks after treatment. Fluazuron was not extensively metabolized as unchanged fluazuron accounted for more than $90 \%$ of the total [6].

In addition to taking care of the health of the animal so that it receives the medication in the doses and the correct form, it is important to analyze the safety of the operator. Carrapaticides are poisons that act primarily on the central nervous system (CNS), causing allergies, malformations of organs, tumor processes, and mainly intoxications. Typically, individuals who have contact with these products are the same on the property and, as they often do the handling, tend to decrease care with these toxic substances [7].

Reduced resistance to infectious disease was a welldocumented consequence of primary and acquired immunodeficiencies, but a novel finding following xenobiotic exposure. The awareness of the consequences of altered immune function is the most likely outcome of inadvertent exposure. The human health implications of studies in which chemical exposure reduced resistance to infection drove an early focus on immunosuppression within the toxicology community [12].

Currently there are few available studies on their toxicity to humans, mainly in relation to low concentrations and risks of genetic toxicity. Because of this, an alternative means of performing the first steps of a research would be the in silico and in vitro models.

In silico computational models are developed using several programs that allow the prediction of the risk and danger of various chemical substances according to their molecular structure. There is now a wide range of free software available to predict chemical properties, toxicological parameters, and other effects [13]. For many years, in vitro models have been used for several tests during the research. They are effective in replacing tests on animals that are limited in time and ethical aspects, in addition to the financial burden [14].

In our study, the main objective is to perform the evaluation by computational platforms and in cell culture, searching for data that can serve as a foundation for a better understanding of the toxic effects involved with the accidental contamination of Fluazuron and, thus, to assist the medical community and users to understand the risks inherent in its use.

\section{Material and Methods}

2.1. Chemical. All chemicals were of analytical grade and were acquired from Sigma Chemical Co. (St. Louis, MO, USA).

2.2. Peripheral Blood Mononuclear Cell (PBMC) Cultures. The PBMC cultures were prepared using $10 \mathrm{~mL}$ of venous blood taken from the medial cubital vein of a 23-yearold healthy male volunteer donor who had not consumed alcohol, smoked, or taken any medication that could interfere with the scientific results in the last $72 \mathrm{~h}$. As described in the next section, the number of donors and their characteristics were chosen according to the Organization for Economic Cooperation and Development (OECD) [15]. Blood was collected into a heparin-containing Vacutainer ${ }^{\circledR}$ (approved by the Research Ethics Committee of the Federal University of Pampa, $\mathrm{n}^{\circ}$. 27045614.0.0000.5323). PBMC were isolated with Histopaque-1077 ${ }^{\circledR}$ (Sigma-Aldrich, St. Louis, EUA) and transferred to the culture medium containing $9 \mathrm{~mL}$ of RPMI 1640 supplemented with $20 \%$ fetal bovine serum and $1 \%$ streptomycin/penicillin, as described in previous work [16, 17]. The cells were conditioned in culture flasks and placed in a microenvironment at $37^{\circ} \mathrm{C}$ in $5 \% \mathrm{CO}_{2}$ environment for up to 48 hours.

2.3. Selection of Concentrations for Tests. Due to a lack of studies on the compound, doses were chosen to allow a broad-spectrum evaluation, which enabled the determination of a median lethal concentration $\left(\mathrm{LC}_{50}\right)$ [16]. Therefore, concentrations of $100 \mu \mathrm{g} / \mathrm{mL}, 10 \mu \mathrm{g} / \mathrm{mL}, 1 \mu \mathrm{g} / \mathrm{mL}, 0.1 \mu \mathrm{g} / \mathrm{mL}$, and $0.01 \mu \mathrm{g} / \mathrm{mL}$ were initially tested in cultures of PMBC, and, after analysis of cell proliferation, the $\mathrm{LC}_{50}$ was determined. The $\mathrm{LC}_{50}$ was determined by the statistical method of nonlinear regression. Brazil follows the security assessment protocols proposed by the Organization for Economic Cooperation and Development (OECD). The tests performed here were selected and followed the indications of these protocols for their experimental design when applicable or 


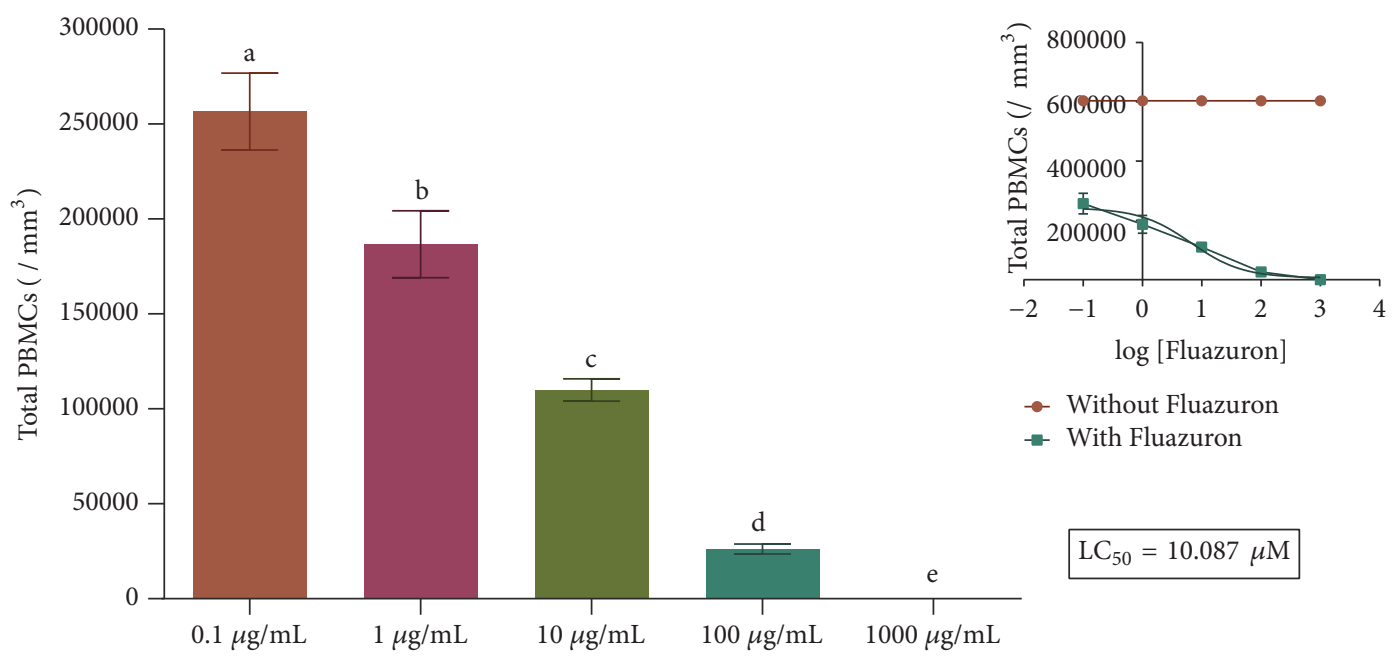

Figure 2: Assessment of cell proliferation for determining the $\mathrm{LC}_{50}$ of Fluazuron in PBMC Culture. Inset shows the nonlinear regression curve. Data are expressed as mean \pm standard deviation, $n=3$, performed in triplicate. We considered significant results with $\mathrm{p}<0.05$ for the samples. Different letters mean statistically different values.

the indications when suggested. The selected concentrations were based on these OECD indications and relate to decimal fractions of the $\mathrm{LC}_{50}$ found.

2.4. Treatment of the Cultures. All cultures received Fluazuron diluted in RPMI 1640 in the final volume of $1000 \mu \mathrm{L}$. The groups tested were the following: Negative Control (NC) with phosphate buffer pH 7.4, Positive Control (PC) with Colchicine $10 \mu \mathrm{M}$, and three concentrations of the acaricide Fluazuron. These concentrations were chosen, as mentioned, based on the $\mathrm{LC}_{50}$, as indicated by the OECD. All tests were performed in triplicate. All analyses were performed at time zero, 24 hours, and 48 hours after exposure to Fluazuron.

2.5. Effects of Fluazuron on the Cell Viability. The analyzed parameter for evaluation of cytotoxicity was cell viability through the loss of membrane integrity using the trypan blue method [17]. This requires putting the sample in contact with the Trypan blue, which stains dead cells. The analysis was performed using an optical microscope at 400x. One hundred cells were counted.

2.6. Genotoxicity Assessment (Alkaline Comet Assay). This test was performed using the technique described by Singh [18] and Rice-Evans [19]. DNA damage was classified according to the damage index evaluated from the migration of the DNA proteins, which can vary from 0 , where there is no damage, until 4 , where there is maximum damage. DNA damage was determined as DNA damage index (ID). DNA damage was calculated from cells with different damage classifications; the damage index ranges from 0 (100 cells $\mathrm{x}$ 0 when no damage occurred) to 400 (100 cells $\mathrm{x} 4$, when maximum damage occurred).

2.7. Mutagenicity Assessment (Micronucleus Test). The micronucleus test was the parameter used to evaluate mutagenicity. For this, the method described was performed according to description by Schmid [20] and Fenech [21].
2.8. Determination of Lymphocyte Subpopulations. Characterization of lymphocyte subpopulations was performed by fluorescence-activated cell sorting (FACS) analysis. The detection of the immune cell fractions was determined using anti-CD45, anti-CD3, anti-CD8, and anti-CD4 antibodies. 15,000 lymphocytes were counted per sample per replicate.

2.9. In Silico Analyses. In a complementary way and to search for possible methods of action in humans, the compound Fluazuron was submitted to a series of computational tests (In Silico) through the platforms: ProTox [8], Way2Drug [10], and GeneCards [11]. The addresses of these platforms are in the references.

2.10. Statistical Analysis. All analyses were performed in specific statistical software. Normality distribution analysis was performed by the Kolmogorov-Smirnov test. With the verification that the distribution followed a Gaussian standard, data were evaluated by one-way analysis of variance (ANOVA) followed by Tukey Post-Hoc test. Results are expressed as means \pm S.D. A p value $<0.05$ was considered significant. Negative controls and positive presented, in all tests, a statistical difference with $\mathrm{p}<0.0001$.

\section{Results and Discussion}

As we mentioned, the first protocol aimed at determining the best concentrations to perform the experiment. To do so, we tested a wide curve of Fluazuron concentrations, and the parameter used as standard was cell proliferation, following OECD protocols. The results obtained are shown in Figure 2.

Once the cytotoxicity curve was reached in PBMC, we found that the lethal concentration was close to $10 \mu \mathrm{M}$. From this value, the test concentrations for the other protocols were determined as 10,1 , and $0.1 \mu \mathrm{M}$.

The other protocols of this experiment were evaluated at three times: initial, 24 , and 48 hours after exposure to 
TABLE 1: Computational analysis of probable toxicity mechanisms for Fluazuron using the PROTOX-II Platform [8].

\begin{tabular}{lcc}
\hline Target & Prediction & Probability \\
\hline Hepatotoxicity & Active & 0.72 \\
Carcinogenicity & Active & 0.56 \\
Immunotoxicity & Active & 0.55 \\
Mutagenicity & Inactive & 0.93 \\
Cytotoxicity & Active & 0.51 \\
Aryl hydrocarbon Receptor (AhR) & Inactive \\
Androgen Receptor (AR) & Inactive \\
Androgen Receptor Ligand Binding Domain (AR-LBD) & Inactive \\
Aromatase & Inactive \\
Estrogen Receptor Alpha (ER) & Inactive \\
Estrogen Receptor Ligand Binding Domain (ER-LBD) & Inactive \\
Peroxisome Proliferator Activated Receptor Gamma & Inactive \\
Heat shock factor response element (HSE) & Inactive \\
Mitochondrial Membrane Potential (MMP) & Active \\
Phosphoprotein (Tumor Suppressor) p53 & Active \\
ATPase family AAA domain-containing protein 5 & Inactive \\
\hline
\end{tabular}

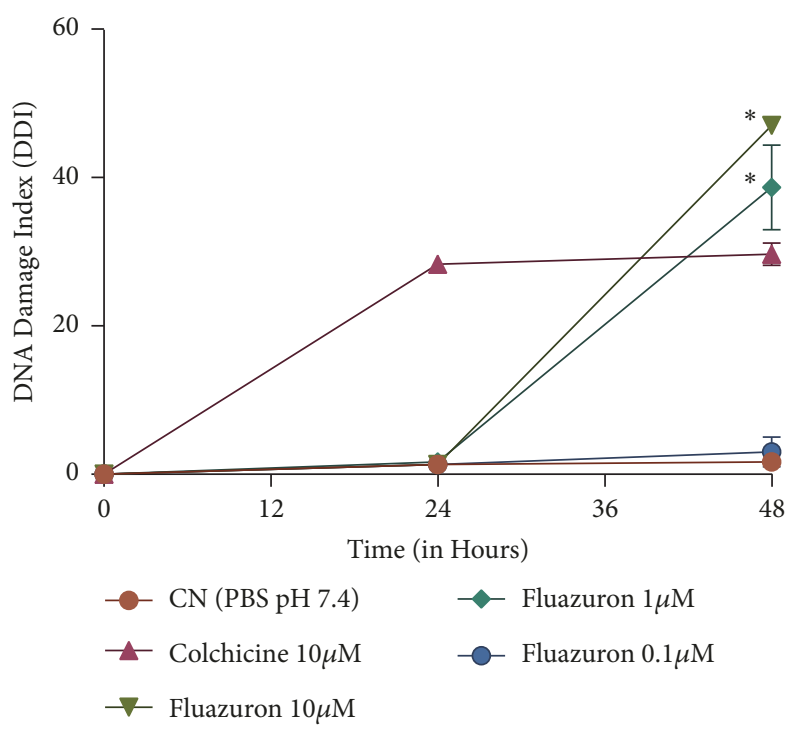

(a)

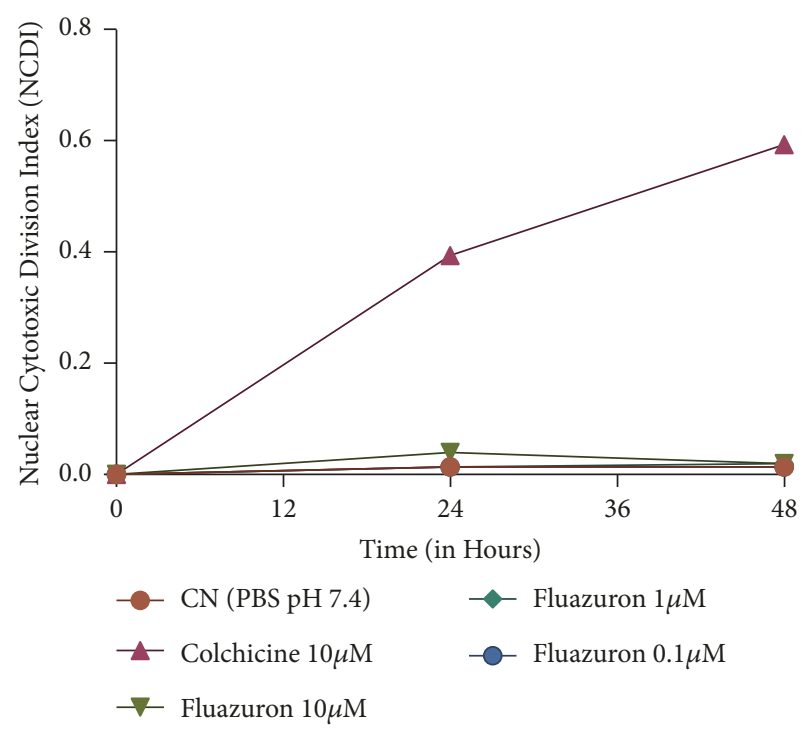

(b)

FIGURE 3: Evaluation of Genotoxicity (a) and Mutagenicity (b) in human PBMC culture, exposed to Fluazuron. Data are expressed as mean \pm standard deviation, $n=3$, performed in triplicate. We considered significant results with $\mathrm{p}<0.05$ for the samples. Different letters mean statistically different values.

Fluazuron concentrations. The results are shown in Figures 3 and 4.

As we can see, no concentration tested showed mutagenic effects in the experiment period $(p<0.05)$. The same cannot be said about genotoxic effects. It can be observed in Figure 3(a) that concentrations of 10 and $1 \mu \mathrm{M}$ cause lesions higher than those caused by the positive control itself in 48 hours of exposure. Although there are no studies that relate the direct effects of Fluazuron on DNA, we can associate this damage with that proposed by the In Silico PROTOX platform, which is shown in Table 1.
As we see, the results of Table 1 agree with those found in the experiment, both for mutagenesis and for genotoxicity (carcinogenesis). Protox uses the system of comparison of molecular fractions to analyze its results. This comparison is made with a database of more than 4000 studies of molecules, thus being a very robust and reliable method [22].

Also, chemically Fluazuron is characterized as a 2,6difluorobenzamide. This molecule has been previously studied and its deleterious effects on DNA are already known. Its action occurs by causing the production of pyknotic nuclei by the disorganized rearrangement of the nuclear chromatin [23]. 


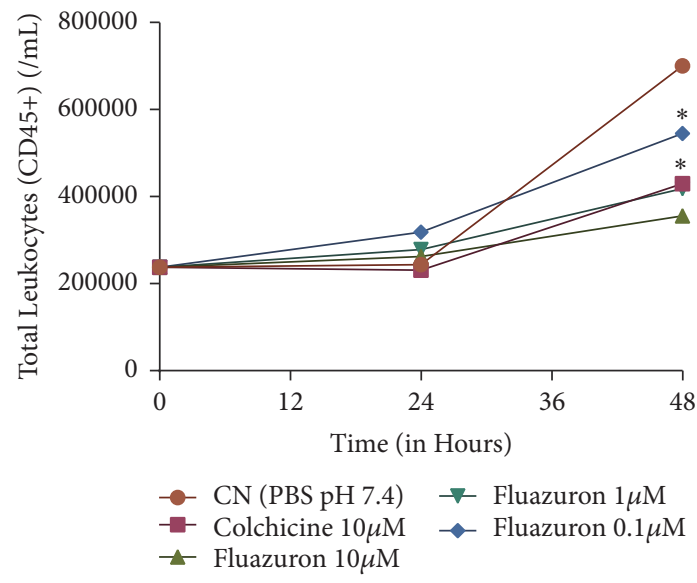

(a)

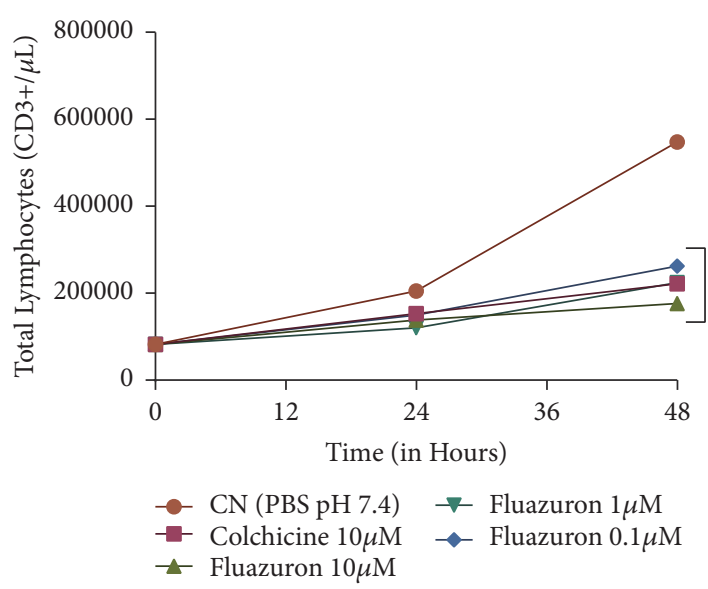

(c)

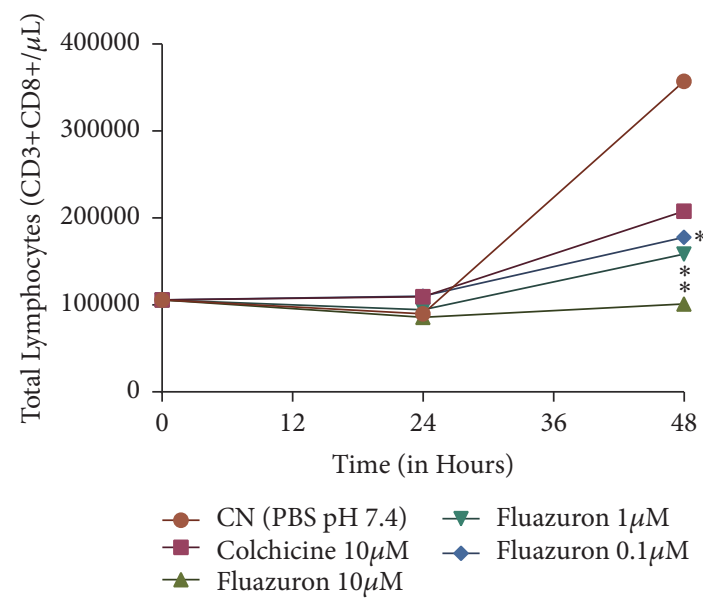

(e)

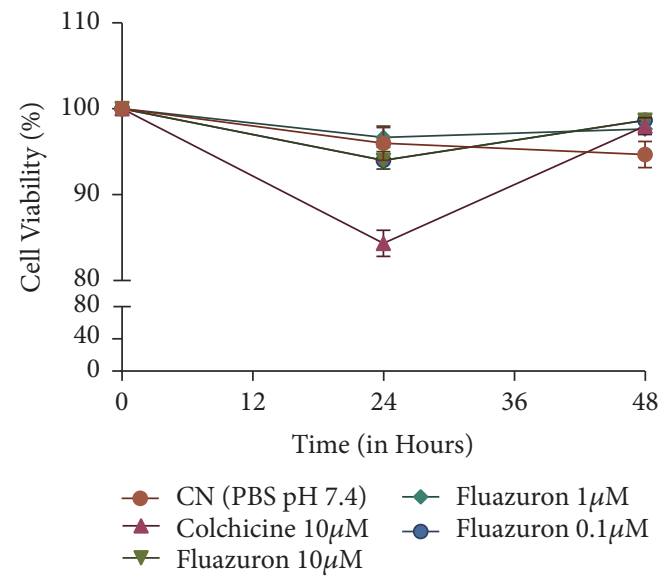

(b)

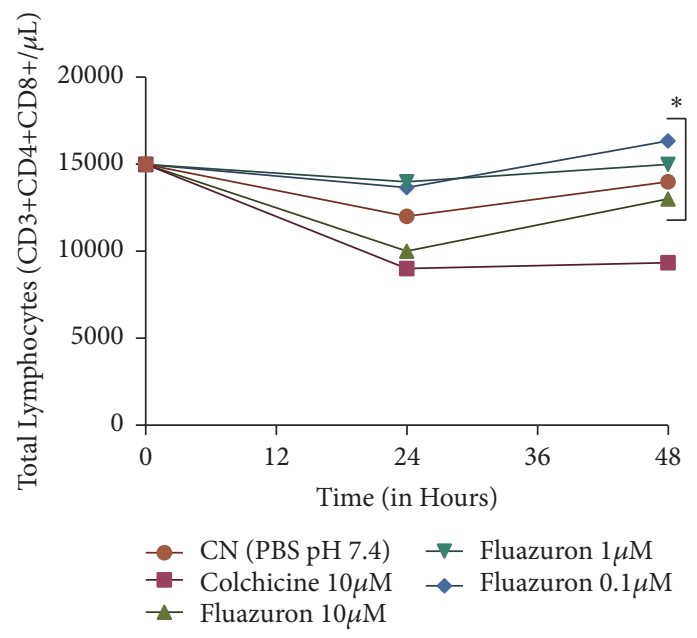

(d)

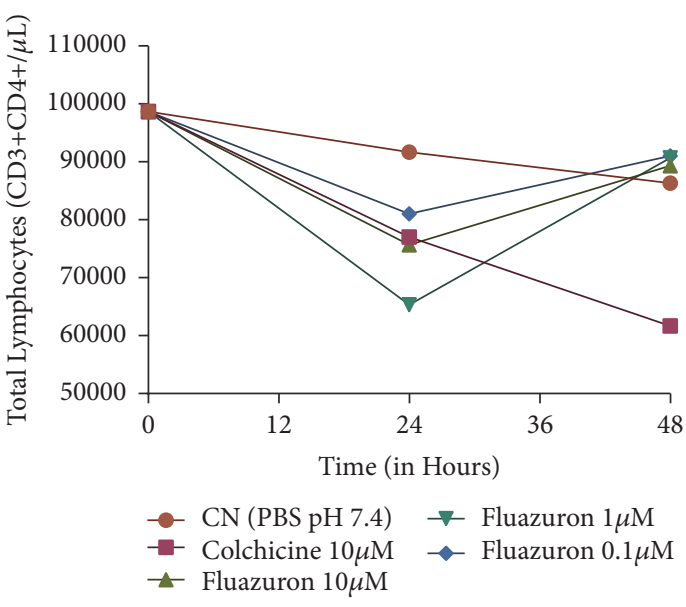

(f)

FIGURE 4: Evaluation of Cytotoxicity of Fluazuron in human PBMC culture. Graph (a) represents the effects on total leukocytes and on (b) the effects on viability. The (c)-(f) graphs show the effects of Fluazuron on lymphocyte subpopulations. Data are expressed as mean \pm standard deviation, performed in triplicate. $*$ represents a significant difference in relation to the negative control $(\mathrm{p}<0.005)$ in the same contact time. 
TABLE 2: Computational analysis of probable biological interactions for Fluazuron using the Way2Drug Platform [10] Associated with Genecards Databank [11].

\begin{tabular}{|c|c|c|}
\hline Target & Prediction & Genecards information \\
\hline Cytokine production inhibitor & Active & - - - - \\
\hline DNA polymerase I inhibitor & Active & ----- \\
\hline Increases expression of the ATG5 gene & Active & $\begin{array}{l}\text { Protein involved in the formation of the } \\
\text { Autophagic Vesicle in Cell Death. }\end{array}$ \\
\hline Reduces expression of the CCNC gene & Active & Cyclin protein involved in apoptosis routes. \\
\hline Reduces IFNG gene expression & Active & $\begin{array}{c}\gamma \text { Interferon protein, important mediator of the } \\
\text { immune system. }\end{array}$ \\
\hline
\end{tabular}

When analyzing the results of cytotoxicity, we observed that all concentrations caused a decrease in the total growth of leukocytes and lymphocytes (Figures 4(a) and 4(c)), but without reducing the viability of the remaining cells (Figure 4(b)). When we evaluated the lymphocyte subpopulations, we observed that this reduction was due to the specific reduction in the number of CD8 T lymphocytes (cytotoxic) (Figures $4(\mathrm{~d})-4(\mathrm{f}))$.

This is the first time that the effects of Fluazuron immunomodulators are evaluated in lymphocyte subpopulations. Again, we can make use of in silico tools to elucidate the mechanisms involved in this action. Table 2 shows the results of the evaluation by the Way2Drug Platform associated with Genecards Databank. In these platforms are demonstrated the possible interactions of Fluazuron in biological activities and gene expressions that may be related to the actions verified here.

Inhibition of cytokine production is shown to complement information on the reduction of gamma interferon gene expression. Perhaps this is the most expressive information for the action seen here. The immune system is known to act as a messaging system with multiple exchanges of information along the route. Cytokines are commonly seen as the mediators of these information passages [24]. Without them, the cells are not activated, and the immune response does not continue, which means that there is no need to proliferate the defense cells because there is no defense to be made once the message has been lost [25]. Gamma interferon is one such messenger. Its function is, among others, to activate CD8 $\mathrm{T}$ lymphocytes. A reduction in its production leads to a reduction in the continuity of the immune response and to a nonactivation of this subpopulation. With this nonactivation, the cells do not proliferate, and the immune response is weakened, just like the organism [26].

If we consider the information that already postulated that Fluazuron can remain in the body for up to three to four weeks, we are talking about a failure in the immune system that can last up to 30 days, leaving the body totally open to infections and/or unresponsive to pathogens.

Summarizing, Fluazuron can cause genotoxicity by probable chromatin rearrangement and immunodepleting by specific reduction of the CD8 T lymphocyte subpopulation, mediated by the decrease in gamma interferon production. Although the use of Fluazuron is a necessity for tick control and for cattle management, we must bear in mind that the imminent risks to its application exist. Careless use can damage the immune system which in turn carries a gigantic hazard by opening a door to diseases and pathogens and leaving us defenseless. It is up to the health professionals to emphasize the importance of the correct application of the product, as well as the use of protection equipment, but, above all, it is the responsibility of the dissemination of this information.

\section{Data Availability}

The data used to support the findings of this study are available from the corresponding author upon request.

\section{Conflicts of Interest}

The authors declare that they have no conflicts of interest.

\section{References}

[1] R. P. D. Mendonça, "Atividade endectocida, segurança clínica e farmacocinética de resíduos de uma nova alternativa terapêutica (Fluazuron+ Abamectina) em bovinos," 2010.

[2] L. F. Vilela, I. J. A. de Sousa, M. H. P. Fontoura et al., Eficácia De Ectoparasiticidas Contra O Rhipicephalus (Boophilus) Microplusem Bovinos Na Região De Paraíso Do Tocantins, vol. 15, Revista Integralização Universitária, 2016.

[3] J. Martins, Carrapato Boophilus Microplus (Can. 1887)(Acari: Ixodidae) Resistente A Ivermectina, Moxidectina E Doramectina, Rio Grande do Sul, Brazil, 2006.

[4] M. R. Couto Filho, G. R. Gonçalves, and P. C. Marino, "Eficácia do controle químico de carrapatos rhipicephalus (boophilus) microplus em bovinos leiteiros com uso de fluazuron: relato de caso," Revista uningá, vol. 53, no. 2, 2018.

[5] C. N. E. Duran, N. E. A. Berni, and G. P. D. Marcato, Polymer Nanoparticles Containing Amitraz And/or Fluazuron, Production Method, Formulation and Uses, 2014.

[6] Meeting JFWECoFA and Organization WH, "Toxicological evaluation of certain veterinary drug residues in food: World Health Organization," 2009.

[7] J. Catto, R. Andreotti, and W. Koller, "Atualização sobre o controle estratégico do carrapato-do-boi. Embrapa Gado de Corte-Comunicado Técnico (INFOTECA-E)," 2010.

[8] M. N. Drwal, P. Banerjee, M. Dunkel, M. R. Wettig, and R. Preissner, "ProTox: A web server for the in silico prediction of 
rodent oral toxicity," Nucleic Acids Research, vol. 42, no. 1, pp. W53-W58, 2014.

[9] S. Kim, P. A. Thiessen, E. E. Bolton et al., "PubChem substance and compound databases," Nucleic Acids Research, vol. 44, no. D1, pp. D1202-D1213, 2016.

[10] D. A. Filimonov, A. A. Lagunin, T. A. Gloriozova et al., "Prediction of the biological activity spectra of organic compounds using the PASS online web resource," Chemistry of Heterocyclic Compounds, vol. 50, no. 3, pp. 444-457, 2014.

[11] M. Safran, I. Dalah, J. Alexander et al., "GeneCards Version 3: the human gene integrator," Database, vol. 2010, Article ID baq020, 2010.

[12] D. Germolec, R. Luebke, A. Rooney, K. Shipkowski, R. Vandebriel, and $\mathrm{H}$. van Loveren, "Immunotoxicology: A brief history, current status and strategies for future immunotoxicity assessment," Current Opinion in Toxicology, vol. 5, pp. 55-59, 2017.

[13] J. Costa Victal, L. Brisighelo Valério, M. Cardoso Oshiro, S. Costa Baptista, and F. Pinheiro, "Métodos alternativos in vitro e in silico: métodos auxiliares e substitutivos à experimentação animal," Revista Intertox de Toxicologia, Risco Ambiental e Sociedade, vol. 7, no. 2, 2015.

[14] A. B. Raies and V. B. Bajic, "In silico toxicology: computational methods for the prediction of chemical toxicity," Wiley Interdisciplinary Reviews: Computational Molecular Science, vol. 6, no. 2, pp. 147-172, 2016.

[15] OECD, “Test no. 487: in vitro mammalian cell micronucleus test, OECD guidelines for the testing of chemicals, section 4," Health Effects, 2014.

[16] C. M. Güez, R. O. de Souza, P. Fischer et al., "Evaluation of basil extract (Ocimum basilicum L.) on oxidative, antigenotoxic and anti-inflammatory effects in human leukocytes cell cultures exposed to challenging agents," Brazilian Journal of Pharmaceutical Sciences, vol. 53, no. 1, 2017.

[17] M. E. Burow, C. B. Weldon, Y. Tang et al., "Differences in susceptibility to tumor necrosis factor $\alpha$-induced apoptosis among MCF-7 breast cancer cell variants," Cancer Research, vol. 58, no. 21, pp. 4940-4946, 1998.

[18] N. P. Singh, M. T. McCoy, R. R. Tice, and E. L. Schneider, "A simple technique for quantitation of low levels of DNA damage in individual cells," Experimental Cell Research, vol. 175, no. 1, pp. 184-191, 1988.

[19] C. A. Rice-Evans, N. J. Miller, and G. Paganga, "Structureantioxidant activity relationships of flavonoids and phenolic acids," Free Radical Biology \& Medicine, vol. 20, no. 7, pp. 933956, 1996.

[20] W. Schmid, "The micronucleus test," Mutation Research/ Environmental Mutagenesis and Related Subjects, vol. 31, no. 1, pp. 9-15, 1975.

[21] M. Fenech, "The in vitro micronucleus technique," Mutation Research, vol. 455, no. 1-2, pp. 81-95, 2000.

[22] L. S. Gold, T. H. Slone, N. B. Manley et al., "The Carcinogenic Potency Database: Analyses of 4000 chronic animal cancer experiments published in the general literature and by the U.S. National Cancer Institute/National Toxicology Program," Environmental Health Perspectives, vol. 96, pp. 11-15, 1991.

[23] A. A. Abou Gabal, "Micro and macro genetic damage induced by the insecticide Match in mice genome," Arab Journal of Biotechnology, pp. 437-452, 2006.

[24] J. J. O'Shea, M. Gadina, and R. M. Siegel, "Cytokines and cytokine receptors," in Clinical Immunology, pp. 127-155, Elsevier, 5th edition, 2019.
[25] Y. Liang, C. Yang, Q. Zhou et al., "Serum monokine induced by gamma interferon is associated with severity of coronary artery disease," International Heart Journal, vol. 58, no. 1, pp. 24-29, 2017.

[26] G. Abril-Rodriguez and A. Ribas, "SnapShot: immune checkpoint inhibitors," Cancer Cell, vol. 31, no. 6, pp. 848-848.e1, 2017. 


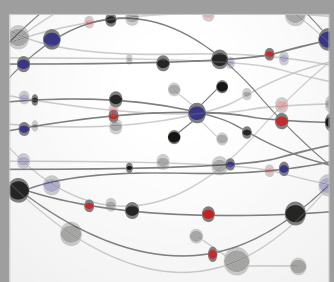

The Scientific World Journal
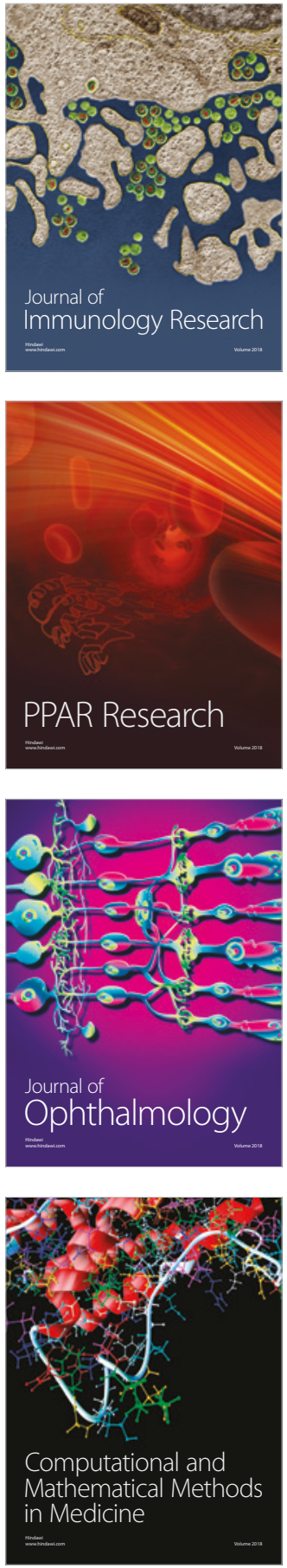

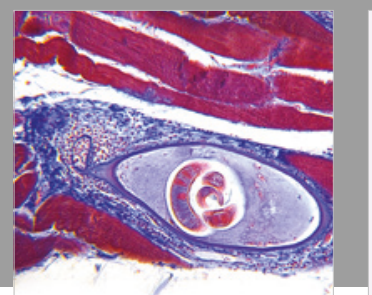

Gastroenterology Research and Practice

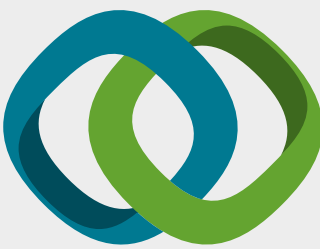

\section{Hindawi}

Submit your manuscripts at

www.hindawi.com
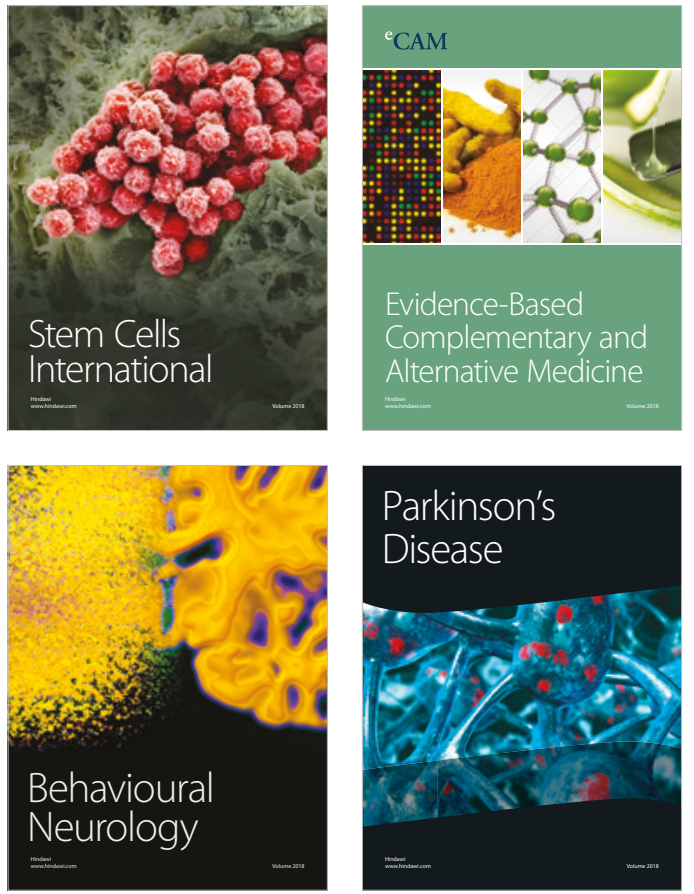

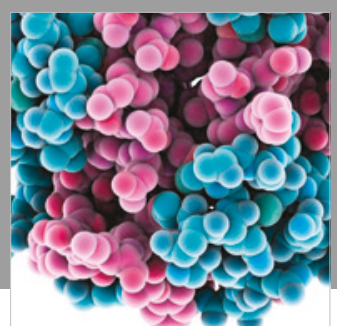

ournal of

Diabetes Research

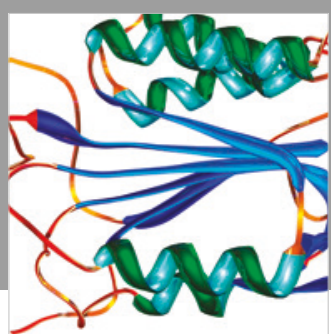

Disease Markers
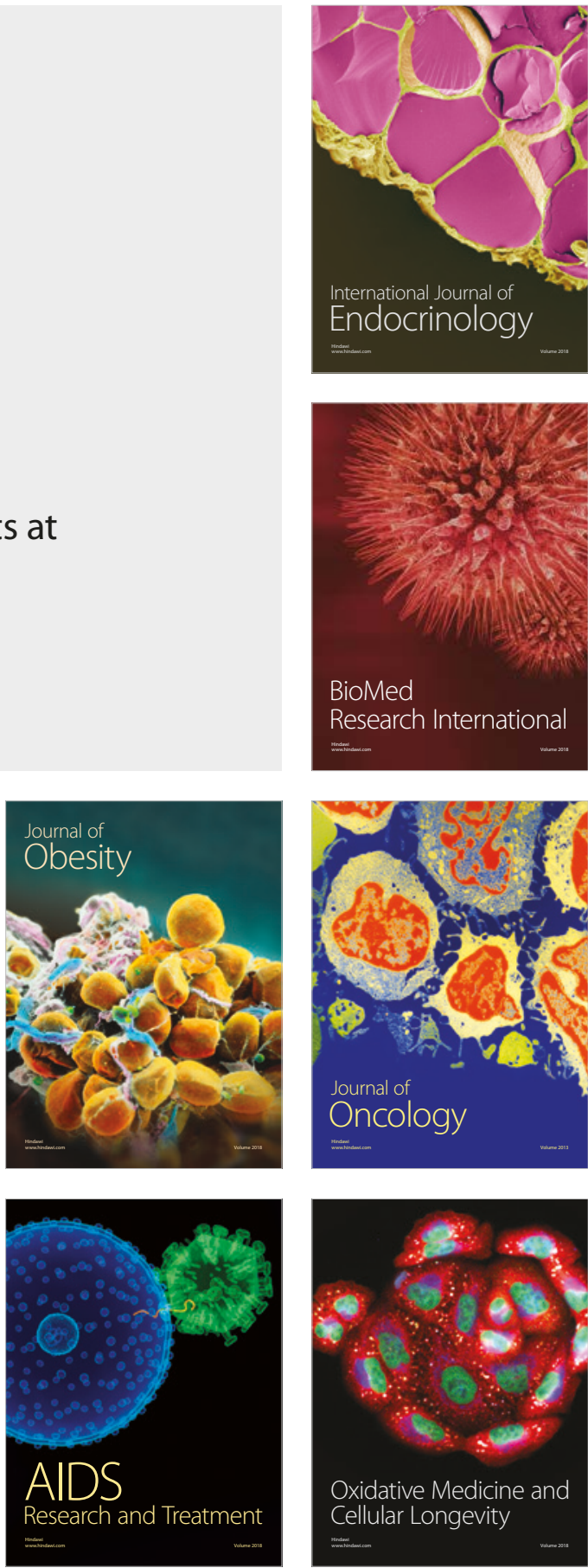